\title{
Tax Challenges For Electronic-Commerce Activities
}

\author{
Hang Nguyen, Coastal Carolina University, USA \\ Meredith DeCenzo, Coastal Carolina University, USA \\ Meyer Drucker, Coastal Carolina University, USA
}

\begin{abstract}
Taxation of commercial transactions has always been a controversial and complex matter to administer for federal and state taxing authorities. Globalization of trade in the market-place, along with the emergence of new advanced technology, including the Internet, has imposed many new challenges for these taxing authorities because the systems in place were designed with a more simple business model in mind.
\end{abstract}

With the expansion of E-Commerce, state and local taxing authorities fear that their tax base will be eroded. Overall, only ten states have passed laws requiring online retailers to collect sales tax; however, the practices still vary amongst each state. Without a uniform e-commerce sales tax system, firms such as Amazon will continue to take advantage of the loopholes in the current system and will relocate production and sales activity to those tax-free states in order to avoid collection responsibility. For example, over the past year, the largest online retailer has challenged states that force it to collect sales tax through a lawsuit, a ballot initiative, and especially through one of politicians' deepest fears-jobs. In South Carolina, Amazon won a four and a half-year exemption on collecting sales tax in exchange for a plan that creates 2,000 jobs and $\$ 125$ million in capital investments to the state through the end of 2013.

One of the major problems is that lawmaking is usually a slow and tedious process. Technology, however, proceeds and evolves at unparalleled speeds. Any legal change to the current taxation system requires serious attention and consideration by governments and tax professionals. Therefore, this research will provide an overview of the problems raised by taxation of ecommerce, and arrive at some proposed initiatives that need to be undertaken to promote as much equity as possible for all parties, including the "Bricks and Mortar Merchants," as well as the ecommerce businesses.

Keywords: Tax Avoidance; Tax Policy; Evasion; Illegal or Legal; Internet; Electronic-commerce; Taxation of Ecommerce; Sales Tax; Amazon Sales Tax; South Carolina Sales Tax; Bricks and Mortar Merchants

\section{INTRODUCTION}

lobalization and the emergence of new advanced technology have created an extremely complex electronic-commerce model and imposed many challenges to the current tax systems that were previously designed with a traditional, simple business model in mind. Modern technology and the Internet have now produced a borderless, virtual business transaction that brings various groups of buyers, suppliers, agents, and consumers from all over the world. These ambiguous tax issues exist at both the state and federal levels. The clarification of income source and tax jurisdiction has become a major problem and places increasing pressure on the current principles governing taxation of sales transactions over the Internet. A typical example below (Figure 1) gives a clearer picture of how the electronic-commerce model has significantly influenced current U.S sales tax systems and changed tax results for the governments: 


\begin{tabular}{|c|c|c|c|}
\hline Purchase Option & $\begin{array}{c}\text { Sales Tax For South } \\
\text { Carolina } \\
\end{array}$ & $\begin{array}{c}\text { Additional Local Sales Tax } \\
\text { For X County }\end{array}$ & Total Sales Tax Paid \\
\hline $\begin{array}{l}\text { 1. Buys the book at a bookstore } \\
\text { in X county }\end{array}$ & $6 \%$ & $1 \%$ & $7 \%$ \\
\hline $\begin{array}{l}\text { 3. Buys the book from the web } \\
\text { site of the bookstore in } \mathrm{X} \\
\text { county and has it mailed to him }\end{array}$ & $6 \%$ & $1 \%$ & $7 \%$ \\
\hline $\begin{array}{l}\text { 4. Buys the book from an } \\
\text { international vendor over } \\
\text { Amazon }\end{array}$ & $\begin{array}{c}0 \% \\
(6 \% \text { use tax owed) }\end{array}$ & $\begin{array}{c}0 \% \\
(1 \% \text { use tax owed) }\end{array}$ & $\begin{array}{c}0 \% \\
\text { (7\% use tax owed) }\end{array}$ \\
\hline $\begin{array}{l}\text { 5. Buys the book in kindle } \\
\text { version (digital form) and has it } \\
\text { uploaded to his tablet: John's } \\
\text { best bet to minimize the sales } \\
\text { tax consequence }\end{array}$ & $\begin{array}{c}0 \% \\
\text { (no tax owed on } \\
\text { intangibles) }\end{array}$ & $\begin{array}{c}0 \% \\
\text { (no tax owed on } \\
\text { intangibles) }\end{array}$ & $\begin{array}{c}0 \% \\
\text { (no tax liability) }\end{array}$ \\
\hline
\end{tabular}
tax consequence

Figure 1: How electronic-commerce model changes tax consequences for the U.S. government entities Note: The statewide sales and use tax rate is six percent $(6 \%) .{ }^{1}$ Assume that X County imposes an additional one percent (1\%) local sales tax.

\section{TAX SYSTEM CHALLENGES FROM ELECTRONIC-COMMERCE SYSTEM}

\section{Electronic-Commerce Concepts \& Trends}

Electronic-commerce or E-commerce (EC hereinafter) is an economic activity that involves the exchange of goods and services between two or more parties using electronic tools and techniques. Some widely used forms of EC include but are not limit to the World Wide Web (WWW), Electronic Data Interchange (EDI), Electronic Funds Transfer (EFT) and E-mail. Examples of EC markets include: Online Auction Sellers, Online Retail \& Services, Online Bartering, Online Gambling / Gaming, and Online Business-to-Business transactions. There are three categories of EC transactions: business-to-business (B2B), business-to-consumer (B2C) and consumer-to- consumer (C2C). For years, EC has been carried out over the Internet and has become the vehicle driving the phenomenal growth of the Internet industry. It has redefined the economic market over the years and changed the way consumers, suppliers, and businesses interact and work internally (Figure 2$)^{2}$

Many firms favor EC because it promotes the trimming of service costs while increasing the speed of service delivery. EC is considered the most effective means for companies to expand rapidly into high-growth and emerging markets across the world while saving important advertising, communication, and administrative costs. The technology that is used by EC can increase responsiveness by notifying individual customers when new products in their areas of interest become available, and by creating customized products and services. Companies using EC can increase their knowledge about consumer habits, be able to define trends, and turn consumer needs into long-term customer relationships.

\footnotetext{
${ }^{1}$ Sales \& Use Tax. Retrieved December 5, 2011 from South Carolina Department of Revenue: http://www.sctax.org/Tax+Information/Sales+and+Use+Tax/default.htm

${ }^{2}$ Omar, Adan, Kwun, Obyung and Bhutta, Khurrum S (2008). The Impact Of E-Commerce Tax Policy On State And Local Government Revenue. Retrieved March 30, 2011 from Department of Management Information Systems Southern University at New Orleans: http://www.swdsi.org/swdsi08/paper/SWDSI\%20Proceedings\%20Paper\%20S150.pdf
} 


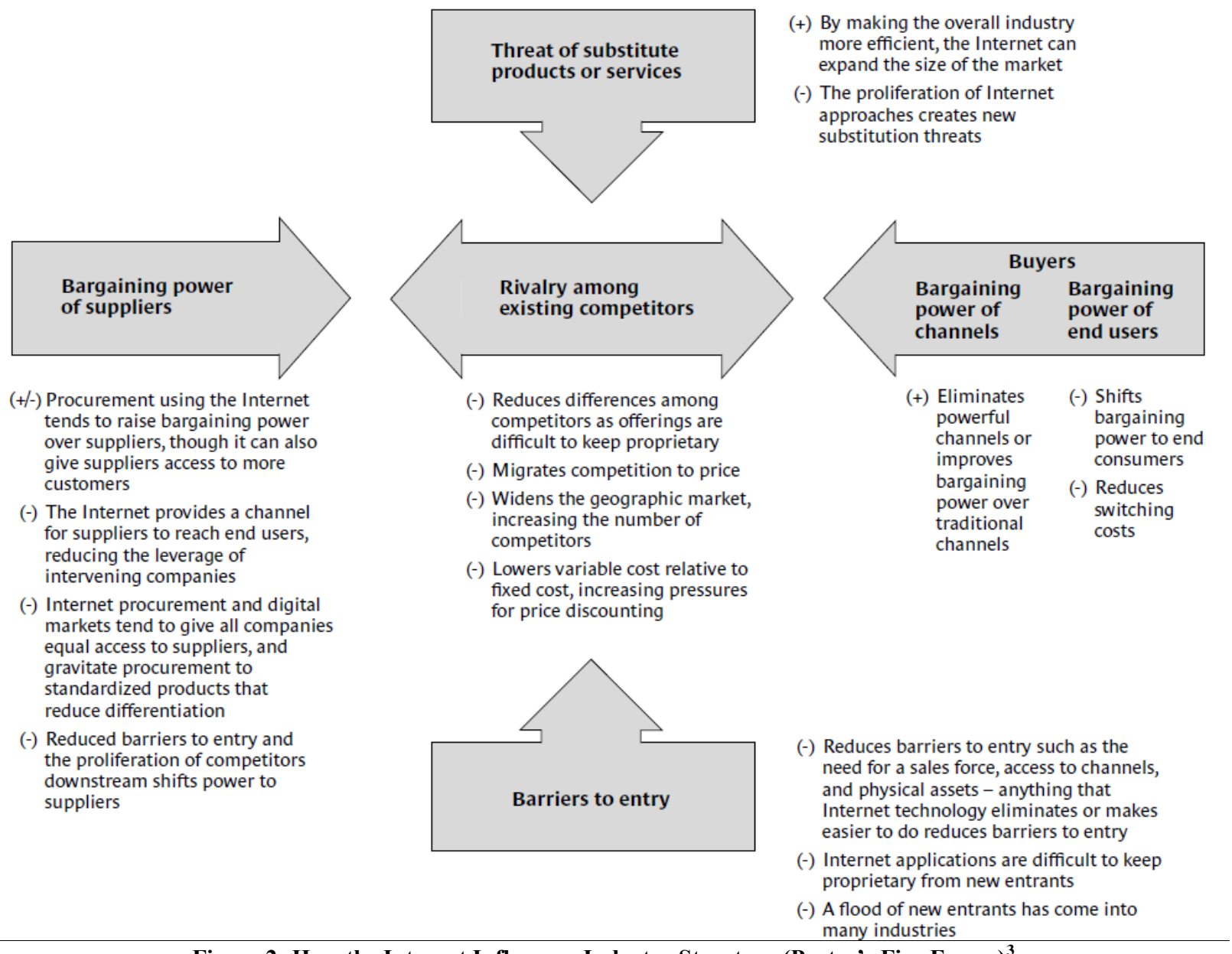

Figure 2: How the Internet Influences Industry Structure (Porter's Five Forces) ${ }^{3}$

Due to significant EC influences, customers now view many online capabilities as "must haves," instead of firms' competitive differentiators. ${ }^{4}$ Therefore, online retailers need to stay on top of the latest EC trends to preserve their brand and drive customer loyalty.

According to a 2011 report on EC conducted by J.P. Morgan, EC investment and growth will be stronger than ever in the next few years. U.S. EC sales are predicted to reach $\$ 235$ billion by 2013 and global EC revenue will hit an astounding $\$ 963$ billion by 2013. The report indicates that the number of people who shop online keeps increasing (32 percent of consumers are buying at least once per month) and higher income consumers shop online the most often (34 percent of those making $\$ 100,000$ or more are shopping online at least three times per month). Analysts at J.P. Morgan believe that the growth in mobile commerce will probably negatively impact "bricks and mortar" stores. However, one of the biggest potential weaknesses in the growth of e-retail is the possibility of Internet sales tax. ${ }^{5}$

\footnotetext{
${ }^{3}$ Porter, Michael E. (2001). Strategy and the Internet. Harvard Business Review, March 2001, 63-78. Retrieved November 17 , $2011 \mathrm{from} \mathrm{http://softwareengineeringonline.com/cbad725fall2011/StrategyAndTheInternet-Porter.pdf}$

${ }^{4}$ 2011eCommerce Assessment: What are digital retail leaders up to. Retrieved November 17, 2011 from Deloitte: http://www.deloitte.com/assets/Dcom-

UnitedStates/Local\%20Assets/Documents/Consumer\%20Business/us retail 2011\%20eCommerce\%20Assessment 050611.pdf

${ }^{5}$ Khan, Imran (2011, January). Nothing But Net: 2011 Internet Sector Outlook. Retrieved November 17, 2011 from JP Morgan: http://www.slideshare.net/victori98pt/2011-internet-sector-outlook-by-j-p-morgan
} 


\section{Current Challenges of Collecting Electronic-Commerce Sales Tax}

A government's authority to tax had always been based on territory and jurisdiction. These systems now face a serious challenge stemming from the development of EC. The trade in goods and services over the Internet has fundamentally altered the accepted boundaries and conventions. While flaws of the concepts underlying the principles of international consensus on taxation have always existed, those flaws have become much more apparent with the advent of EC.

EC makes numerous concepts difficult to apply, including those such as the concept of permanent establishment (to determine location of manufacture), point of sale (for the application of relevant tax rates), income classification (based on source of income), product classification (for preferred tax rates), etc. Within the borderless world of the Internet, EC effectively imposes challenges on identifying buyers and sellers' locations. ${ }^{6}$ Governments and their tax authorities are finding it increasingly difficult to streamline the harmony between EC development and the current tax system. It is estimated that U.S. tax authorities have lost $\$ 8.6$ billion in uncollected state and local sales tax from EC in $2010 .^{7}$

\section{THE U.S. ELECTRONIC-COMMERCE SALES TAX SYSTEM}

\section{State and Local Sales and Use Tax}

Sales tax is a gross-basis tax imposed on the retail sale of most tangible personal property (unless specifically exempted) and some services (if specifically enumerated). ${ }^{8}$ Sales of intangible property such as stocks, notes, bonds, mortgages, or the transmission of computer database information are generally not subject to sales tax. $^{9}$

Use tax is a "complimentary" tax imposed on the use, storage or consumption of tangible personal property or services within a state where the property was purchased in another state. ${ }^{10}$ The use tax base and rate is generally the same as the sales tax base and rate. ${ }^{11}$ The use tax is generally intended to plug the gap left by a state's jurisdictional inability to levy a sales tax on sales transactions occurring outside its borders. ${ }^{12}$ However, many states have historically viewed the use tax on individuals as impractical to enforce because "the tax typically involves a small amount owed on a large number of transactions for which the individual has not kept records, and the costs of collection could easily exceed the revenues collected." 13

Under the U.S. Constitution (Quill Corporation v. North Dakota, 1992), a taxing jurisdiction cannot require a retailer to collect and remit state and local sales and use taxes unless the retailer has a substantial nexus or

\footnotetext{
${ }^{6}$ Nellen, Annette (2001). Overview To E-Commerce Taxation Issues. Retrieved April 14, 2011 from San Jose Silicon Valley Chamber of Commerce: http://www.cob.sjsu.edu/facstaff/nellen_a/

${ }^{7}$ Bruce, Donald, Fox, William F., and Luna, LeAnn (2009, April 13). State and Local Government Sales Tax Revenue Losses from Electronic Commerce. Retrieved November 17, 2011 from The University of Tennessee:

http://cber.utk.edu/ecomm/ecom0409.pdf

${ }^{8}$ Sec. 12-36-910 (A), South Carolina Sales Tax Guide, South Carolina. Five percent tax on tangible personal property; laundry services, electricity, communication services, and manufacturer-consumed goods. Retrieved April 15, 2011 from CCH Intelliconnect: $\underline{\text { http://intelliconnect.cch.com }}$

${ }^{9}$ Sec. 12-36-60, South Carolina Sales Tax Guide, South Carolina. Tangible personal property. Retrieved April 15, 2011 from CCH Intelliconnect: http://intelliconnect.cch.com

${ }^{10}$ Sec. 12-36-1310(A), South Carolina Sales Tax Guide, South Carolina. Imposition of tax; rate; applicability; credit for tax paid in another state. Retrieved April 15, 2011 from CCH Intelliconnect: http://intelliconnect.cch.com

${ }^{11}$ Sale \& Use Tax. Retrieved April 15, 2011 from South Carolina Department of Revenue: http://www.sctax.org/Tax+Information/Sales+and+Use+Tax/default.htm

${ }^{12}$ Arkansas Sales Tax Guide, II60-020, Arkansas. Application of Sales and Use Taxes. Retrieved April 15, 2011 from CCH Intelliconnect: http://intelliconnect.cch.com

${ }^{13}$ Manzi, Nina (2010, June). Use Tax Collection on Income Tax Returns in Other States. Retrieved November 17, 2011 from Research Department Minnesota House of Representatives: http://www.house.leg.state.mn.us/hrd/pubs/usetax.pdf
} 
a physical presence in the jurisdiction. ${ }^{14}$ Having a substantial nexus does not only necessarily mean that the retailer operates a retail establishment in the state or has employees always present in the state, but also means that the retailer has an agent, affiliate, or a representative who performs services in a state that allows the out-of-state retailer to establish and maintain a marketplace in the state ${ }^{15}$ However, it is important to note that while the remote seller does not report sales or use tax, the in-state buyer is required to self-report and remit the appropriate sales or use tax on the purchase. ${ }^{16}$

\section{Sales and Use Tax On Electronic-Commerce Transactions}

Overall, a sales tax and use tax is imposed by most states on EC transactions. "Such transactions include (1) purchases over the Internet of taxable services and property that are delivered in a non-electronic form and (2) purchases of services or property that are delivered electronically and that may or may not be the equivalent of services or property that also can be delivered by non-electronic means." ${ }^{17}$ While most states impose sales and use tax generally on all sales of tangible personal property, the taxability of sales of digital property delivered electronically varies among the states. "In some states, a sale of certain types of digital property delivered electronically is considered a taxable sale of tangible personal property. In other states, such a sale is treated as not involving the transfer of tangible personal property and, therefore, is nontaxable. And yet in other states, sales of some software delivered electronically are taxable while sales of other items delivered electronically are nontaxable." 17

In general, sales tax issues relating to EC activities have very similar jurisdictional and product classification principles under mail-order purchases. "The obligation of the seller to collect tax on such remote sales depends on whether the seller has nexus with the taxing jurisdiction. If a sale is taxable and the seller does not collect tax, then the buyer generally is responsible for remitting use tax on the transaction." 17

\section{Inconsistent Tax Nexus Issues}

Under both the Due Process and Commerce Clauses of the U.S. Constitution, "nexus between a vendor and a taxing state is a requirement" for a state to collect and remit sales and use tax from vendors. ${ }^{18,19}$ Due Process requires that seller have "minimum contacts" with destination state, not necessarily including physical presence, for nexus to exist. ${ }^{18}$ Therefore, activities such as advertising in the state or sending catalogs into the state will usually be sufficient to establish "minimum contacts." The Commerce Clause requires that seller have "substantial presence" in the destination state, including physical presence, for nexus to exist. ${ }^{19}$ In the context of mail-order retailers (National Bellas Hess, Inc. v. Department of Revenue, and Quill Corporation v. North Dakota), the U.S. Supreme Court has held that out-of-state mail order retailers with no physical presence in the state do not have taxable nexus where their only connection with customers in the state is by U.S. mail and common carrier. ${ }^{20,21}$

\footnotetext{
${ }^{14}$ U.S. Supreme Court Cases, by and through its Tax Commissioner, Heitkamp, U.S. Supreme Court, 504 U.S. 298, (May 26, 1992). Quill Corporation v. North Dakota. Retrieved April 15, 2011 from CCH Intelliconnect: http://intelliconnect.cch.com

${ }^{15}$ Kwiatek, Harlan J., and McGahan, Sarah (2010). Current trends in sales and use tax: click-through nexus and informationreporting requirements. The Tax Adviser 41.12: 870+. Retrieved April 25, 2011 from General One File: $\underline{\text { http://0- }}$ find.galegroup.com.library.coastal.edu

${ }^{16}$ Use Tax. Retrieved April 15, 2011 from Arkansas Department of Finance and Administration Consumer: http://www.dfa.arkansas.gov/offices/exciseTax/salesanduse/Pages/Co.aspx

${ }^{17}$ South Carolina Sales Tax Guide, I60-445, South Carolina, U.S. Constitution. Retrieved April 15, 2011 from CCH Intelliconnect: http://intelliconnect.cch.com

${ }^{18}$ South Carolina Sales Tax Guide, I60-025, South Carolina. Nexus_-Doing Business in South Carolina. Retrieved April 15, 2011 from CCH Intelliconnect: http://intelliconnect.cch.com

${ }^{19}$ South Carolina Sales Tax Guide, $\$ 60-075$, South Carolina, U.S. Constitution. Retrieved April 15, 2011 from CCH Intelliconnect: http://intelliconnect.cch.com

${ }^{20}$ U.S. Supreme Court, I[200-434, Illinois Sales Tax Guide, (May 8, 1967). National Bellas Hess, Inc. v. Department of Revenue. Retrieved April 15, 2011 from CCH Intelliconnect: http://intelliconnect.cch.com

${ }^{21}$ Delaware Sales Tax Guide, by and through its Tax Commissioner, Heidi Heitkamp, U.S. Supreme Court, I[200-488, (May 26, 1992). Quill Corporation v. North Dakota. Retrieved April 15, 2011 from CCH Intelliconnect: http://intelliconnect.cch.com
} 
These two federal jurisdictional limitations on state sales and use tax have portrayed several limitations. First of all, the "substantial presence" standard is not a clear-cut definition, and can be especially uncertain for eretailers who access state markets using in-state electronic communications and computer infrastructure. The National Bellas Hess and Quill cases will probably not be very helpful beyond the limited mail-order setting. "Unlike Due Process limitations, Congress can legislatively waive or limit the protection afforded to out-of-state sellers." 22

Because of unclear nexus standards applied, some states have interpreted and begun to apply these general rules differently depending on certain specific e-commerce contexts. For example, in Virginia, "an out-of-state vendor would not have nexus with Virginia and therefore would not be required to collect and remit Virginia sales and use tax on sales to Virginia customers if its only presence in Virginia is the use of computer servers to create or maintain websites by which customers can view and order products that would be shipped from outside Virginia.",23 On the other hand, under Kansas tax law, a vendor with both a store in Kansas and a web server in California was required to collect use tax on web sales from California into Kansas because the Kansas store had a computer terminal that some of its customers used to access the California web site. ${ }^{24}$

Furthermore, with increasing EC cross-border sales and current budget shortfalls, more states have exploited the unclear "substantial nexus" principles to assert jurisdiction over out-of-state retailers to remit sales tax. ${ }^{15}$ For example, Illinois passed a law requiring Internet companies with affiliates in that state to collect taxes on sales to Illinois customers. ${ }^{25}$ In Vermont and Arkansas, similar bills scored initial legislative victories; New York, California, North Carolina and Rhode Island have amended their laws to adopt similar policies. ${ }^{15,}{ }^{25}$ In Colorado, a law requires online retailers to either collect the tax or send customers an annual notice letting them know how much they owe their state. ${ }^{15}$ Arizona and Massachusetts are considering passing their own flavor of online sales tax collection legislation. ${ }^{25}$

\section{Classification of Issues}

Another longstanding area of dispute over the EC tax principle is the clarification of computer software for sales tax purposes. Because of the complex nature of this technological product, it is hard to clarify if the software is "tangible" (taxable) or "intangible" (nontaxable) property. Some states approach this problem by classifying software as either "canned" or "custom." "Canned" or "prewritten" software that can usually be purchased off the shelf, such as prepackaged word processing programs, game programs, educational programs, spreadsheet programs including bookkeeping and payroll programs, or video game cartridges, is generally treated for sales tax purposes as a sale of tangible property. ${ }^{26}$ "Custom" software is created to serve a particular customer's needs, and is generally nontaxable for sales tax purposes. ${ }^{24,27}$ However, the amount of customization needed to convert "canned" to "custom" software can vary widely from state to state. ${ }^{24}$

\footnotetext{
${ }^{22}$ Gercken, Keith R. (2001, November). E-Commerce: United States Sales and Use Tax Considerations. State \& Local Tax Bulletin. Retrieved November 17, 2011 from Pillsbury Winthrop Shaw Pittman LLP: http://pmstax.com/ftp/state/bull0111.pdf

${ }^{23}$ Virginia Sales Tax Guide, Ruling of Commissioner, P.D. 00-53 (April 14, 2000). Retrieved November 17, 2011 from Internet Library of Law and Court Decisions from: http://www.internetlibrary.com/cases/lib_case290.cfm

${ }^{24}$ Opinion Letter No. O-2000-042, Kansas, [67-115, Kansas State Tax Reporter (Dec. 5, 2000). Retrieved April 15, 2011 from CCH Intelliconnect: http://intelliconnect.cch.com

${ }^{25}$ Metz, Rachel (2011, March 27). States eye tax on Web dealing: Amazon, others not taking it lying down. Retrieved April 15, 2011 from TheSunNews: http://www.thesunnews.com/2011/03/27/2061963/states-eye-tax-on-webdealing.html\#ixzz1KkhCMON9

${ }^{26}$ Revenue Ruling No. 19-2004-03, Kansas State Tax Reporter. Sales and use-- Taxability of persons and transactions-Computers, software, and services-- Software,Kansas,[200-956, (Aug. 31, 2004). Retrieved April 15, 2011 from CCH

Intelliconnect: http://intelliconnect.cch.com

${ }^{27}$ Pennsylvania Sales Tax Guide, $\llbracket[60-310.22$. Canned software licenses. Retrieved April 15, 2011 from CCH Intelliconnect: http://intelliconnect.cch.com 


\section{Taxability of Internet Services}

State tax jurisdiction is also inconsistent on this type of technology. Some states have imposed sales or transaction taxes on services provided by Internet service providers, for example, Tennessee or Illinois. ${ }^{28,29}$ Other states have exempted Internet access charges from both sales tax and telecommunications excise tax, such as Florida or California. ${ }^{30,31}$ Overall, most states exempt Internet access sales tax.

\section{Internet Tax Freedom Act and Streamlined Sales Tax Project}

The current accelerating EC activities and inconsistent state tax jurisdictions have put much pressure on the current EC tax system. Some of the federal and state legislative efforts to simplify and rationalize the existing rules include Internet Tax Freedom Act (ITFA) and Streamlined Sales Tax Project (SSTP). ${ }^{32,33}$ The federal ITFA bars state and local governments from imposing multiple or discriminatory taxes on electronic commerce and taxes on Internet access. This moratorium expires on November 1, 2014. ${ }^{32}$ SSTP was created by a group of representatives from over 35 states to simplify sales and use tax system for all types of vendors, rather than only for on-line vendors. Features of the SSTP proposal include state administration of sales and use tax collections, uniformity in state and local tax bases, a central electronic registration system, uniform sourcing rules, uniform definitions, simplified tax returns, and consumer privacy protections. ${ }^{33}$

\section{TAXING ELECTRONIC-COMMERCE SALES}

\section{Pros}

More than ever, retailers depend on digital means to communicate and transact with their customers. Over the past decade, retail EC sales have increased approximately 24 times faster than non-EC retail sales. ${ }^{34}$ However, many states are not collecting taxes on online transactions. "Across the nation, forty-eight of the fifty states face a budget deficit cumulatively totaling $\$ 196$ billion in 2010, or approximately 29 percent of state budgets." ${ }^{35}$ This has sparked debate in Congress, state, and local governments on whether taxes should be imposed on online transactions as well as who should standardize online taxing: federal, individual states or the local governments. Proponents of taxing Internet commerce believe that exempting EC from sales taxes is "unfair" to "Bricks and Mortar" retail merchants who are required to collect sales taxes. ${ }^{36}$

Furthermore, as the expansion of EC has been increasing significantly over the past years and state and local government tax revenues are reduced, there is widespread fear among state legislators and tax administrators

\footnotetext{
${ }^{28}$ Letter Ruling No. 96-09, Tennessee State Tax Reporter. Sales and use-- Telecommunications-- Internet access charges-- World Wide Web service, Tennessee, $\{[400-493$, (Mar. 4, 1996). Retrieved April 15, 2011 from CCH Intelliconnect: http://intelliconnect.cch.com

${ }^{29}$ Sales \& Use Tax. Retrieved April 15, 2011 from Illinois Revenue:

http://www.revenue.state.il.us/businesses/taxinformation/sales/rot.htm

${ }^{30}$ California State Tax Reporter, $\Psi 60-445$,California. Internet/Electronic Commerce. Retrieved April 15, 2011 from CCH Intelliconnect: $\underline{\text { http://intelliconnect.cch.com }}$

${ }^{31}$ Florida State Tax Reporter,[60-445,Florida. Internet/Electronic Commerce. Retrieved April 15, 2011 from CCH Intelliconnect: http://intelliconnect.cch.com

32 Taxation - Internet Tax Freedom Act. Retrieved December 5, 2011 from Cybertelecom: http://www.cybertelecom.org/ecom/tax.htm

${ }_{33}$ Arizona State Senate Issue Brief (2008, October 28). Internet Taxation. Retrieved November 17, 2011 from http://www.azleg.gov/briefs/Senate/INTERNET\%20TAXATION.pdf

${ }^{34} 2009$ Quarterly E-Commerce Report. Retrieved November 17, 2011 from U.S. Census Bureau: http://www.census.gov/retail/mrts/www/data/html/09Q4table4.html.

${ }^{35}$ McNichol, Elizabeth, and Johnson, Nicholas (2010, February 25). Recession Continues to Batter State Budgets; State Responses Could Slow Recovery. Retrieved November 17, 2011 from Center on Budget and Policy Priorities: http://www.cbpp.org/cms/index.cfm?fa=view\&id=711

${ }^{36}$ Atkinson, Rob, and Castro, Daniel (2010, May 20). Closing the E-Commerce Sales Tax Loophole. Retrieved November 17, 2011 from Information Technology \& Innovation Foundation: http://www.itif.org/files/2010-sales-tax.pdf

(C) 2012 The Clute Institute http://www.cluteinstitute.com/ 
that unless out-of-state sellers can be required to report sales and remit taxes on EC, the local sales and use tax base would be eroded. The potential loss of tax base will impair the governments' ability to improve and/or maintain the existing level of education, health, roads, public safety, youth programs, and many other essential services.

Research from the University of Tennessee has estimated that annual national state and local sales tax losses on EC will grow to $\$ 11.4$ billion by 2012 for a six-year total loss of $\$ 52$ billion (see Figure 3 ). ${ }^{7}$ Although efforts have been made to impose sales tax on all items purchased online in order to decrease losses of revenue within the states, there are inconsistent practices amongst states. Without a uniform EC sale tax system, firms will continue to take advantage of the current loopholes and relocate production and sales activities to tax-free-states to avoid collection responsibility. This will in fact impose economic inefficiencies on the overall national economy. ${ }^{2}$

\begin{tabular}{|c|c|c|c|c|c|c|}
\hline & 2007 & 2008 & 2009 & 2010 & 2011 & 2012 \\
\hline \multicolumn{7}{|l|}{ Baseline E-Commerce Growth Scenario } \\
\hline Total Business-to-Business E-commerce & $2,325,701$ & $2,480,011$ & $2,231,283$ & $2,767,010$ & $3,253,412$ & $3,656,856$ \\
\hline Total Business-to-Consumer E-commerce & 168,081 & 179,233 & 161,257 & 199,975 & 235,128 & 264,285 \\
\hline Total E-Commerce & $\overline{2,493,782}$ & $\overline{2,659,244}$ & $\overline{2,392,540}$ & $\overline{2,966,985}$ & $\overline{3,488,540}$ & $3,921,140$ \\
\hline Estimated Taxes Due & 29,177 & 31,113 & 27,992 & 34,713 & 40,815 & 45,877 \\
\hline Estimated Taxes Collected & 21,931 & 23,386 & 21,041 & 26,093 & 30,679 & 34,484 \\
\hline Estimated Total State and Local Revenue Loss & $\underline{7,246}$ & $\mathbf{7 , 7 2 6}$ & 6,951 & 8,620 & 10,136 & 11,393 \\
\hline \multicolumn{7}{|l|}{ Optimistic E-Commerce Growth Scenario } \\
\hline Total Business-to-Business E-commerce & $2,325,701$ & $2,486,222$ & $2,408,247$ & $3,184,050$ & $3,634,500$ & $4,060,293$ \\
\hline Total Business-to-Consumer E-commerce & 168,081 & 179,682 & 174,047 & 230,115 & 262,669 & 293,442 \\
\hline Total E-Commerce & $\overline{2,493,782}$ & $\overline{2,665,904}$ & $\overline{2,582,294}$ & $\overline{3,414,165}$ & $\overline{3,897,170}$ & $4,353,735$ \\
\hline Estimated Taxes Due & 29,177 & 31,191 & 30,212 & 39,945 & 45,596 & 50,938 \\
\hline Estimated Taxes Collected & 21,931 & 23,445 & 22,710 & 30,025 & 34,273 & 38,288 \\
\hline Estimated Total State and Local Revenue Loss & 7,246 & $\mathbf{7 , 7 4 6}$ & 7,503 & 9,920 & 11,323 & 12,650 \\
\hline
\end{tabular}

Figure 3: National Total State and Local EC Estimated Revenue Losses (in millions) ${ }^{7}$

\section{Cons}

The main argument against taxing EC sales is that such tax could hinder the growth of EC. Especially in this difficult economy, EC is one of the major entrepreneurial industries that supports and improves the current job market. Also, such a tax could danger a state's efforts to attract certain industries. There is no doubt that EC entrepreneurs and high-tech business executives would view EC tax as hostile to their businesses. The imposition of such taxes by other states could also hurt EC start-ups headquartered or located in the state. Tax revenue from new EC has helped fuel state revenue surpluses that existed throughout the country for many years (see Figure 4). Besides, EC retailers and businesses and their employees also pay property, income and all other applicable state and local taxes to the state in which they are located to support local budgets for roads, police, fire and all of the other services and infrastructure for that state and its local governments. ${ }^{37}$

\footnotetext{
${ }^{37}$ Guertin, Mira (2010). Taxing E-Commerce Will Blunt States' High-Tech Edge: Internet Taxation Threatens California Technology Sector Jobs, Small Businesses. Retrieved November 18, 2011 from California Chamber of Commerce: http://www.calchamber.com/governmentrelations/issuereports/documents/2010\%20issue\%20reports/ecommerce_taxation.pdf 


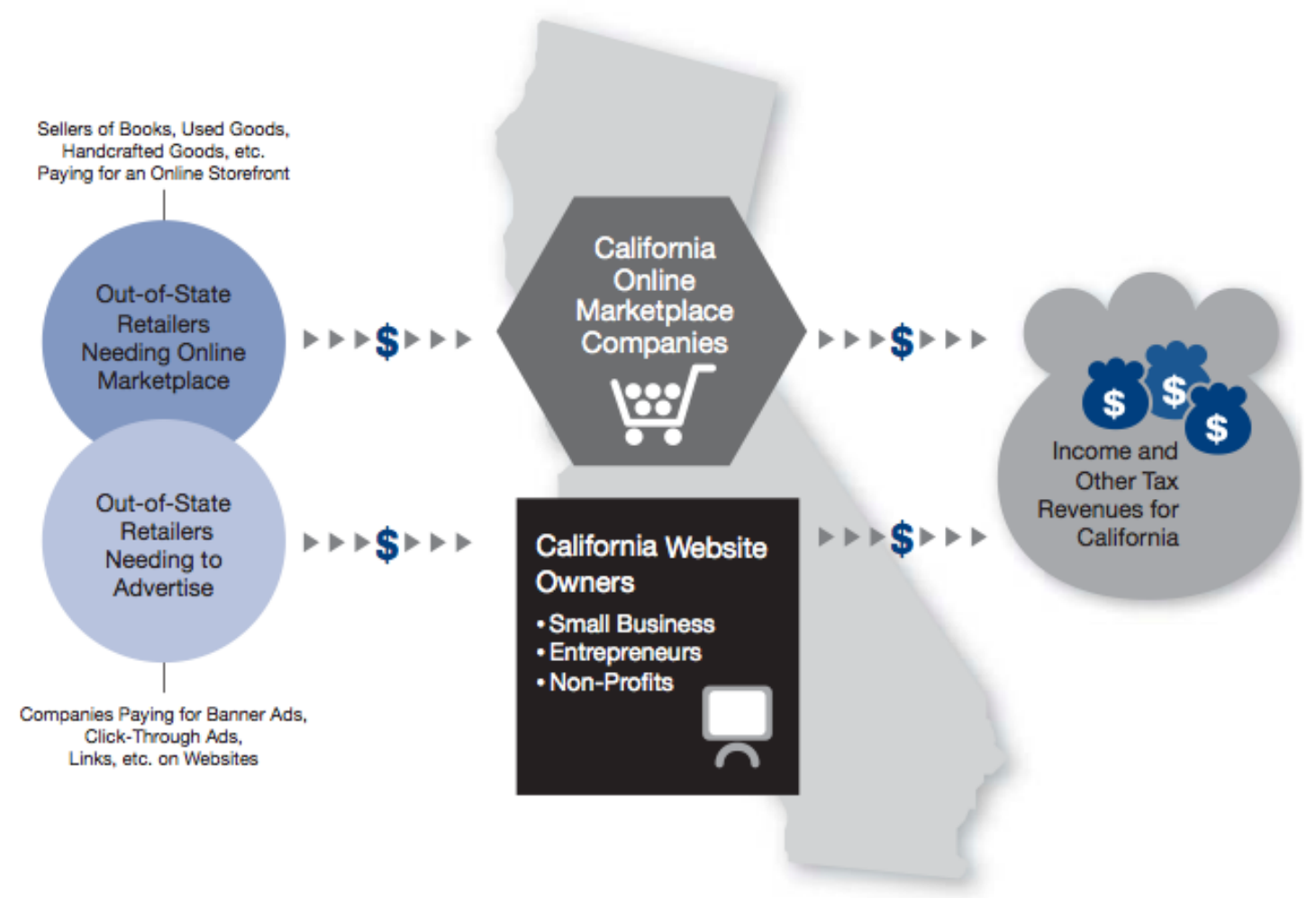

Figure 4: Illustration of How EC Supports A State's Economy: Bringing Jobs, Income and Other Tax Revenues ${ }^{37}$

\section{"Amazon Laws"}

Over the past year, the largest online retailer, Amazon, has fought attempts by New York, California, Texas, Rhode Island, North Carolina, and dozens of other states to levy tax on EC sales. The company has challenged states that force it to collect sales tax through a lawsuit, a ballot initiative, and especially politicians' deepest fear-jobs. ${ }^{38}$ Amazon.com has banned individuals and organizations from these states to participate in its affiliate program and threatened to close its shipping center in these states, fire local workers, and scrap plans to build other facilities in the state. As a result, in South Carolina, Amazon won a four and a half-year exemption on collecting sales tax in exchange for a 2,000 jobs plan and \$125 million in capital investments to the state through the end of $2013 .{ }^{39}$ In Tennessee, legislators delayed until next year the consideration of a bill that would tax online purchases due to Amazon's threat to move its two state distribution centers to Indiana. However, according to analysts, it is going to be a continued fight for the next few years, and the states may ultimately win. ${ }^{40}$

\footnotetext{
${ }^{38}$ Woo, Stu (2011, August 31). Amazon Battles States Over Sales Tax. Retrieved November 18, 2011 from The Wall Street Journal: http://online.wsj.com/article/SB10001424053111904772304576468753564916130.html?mod=ITP_pageone_0

${ }^{39}$ Harrell, Barry (2011, June 20). Amazon negotiating for sales-tax exemption in trade for 5000 news Texas jobs. Retrieved December 2, 2011 from http://www.statesman.com/blogs/content/sharedgen/blogs/austin/politics/entries/2011/06/20/amazon negoitiating for salest.html

${ }^{40}$ Stone, Brad (2011, June). Amazon May Soon Need to Collect Sales Tax. Retrieved November 17, 2011 from Bloomberg Business Week: http://www.businessweek.com/magazine/content/11_24/b4232041319222.htm 


\begin{tabular}{|l|c|}
\hline \multicolumn{1}{|c|}{ State } & State Sales Tax Rate (July 1 $\mathbf{1}^{\text {st }} \mathbf{2 0 1 1 )}$ \\
\hline Arkansas & $6 \%$ \\
\hline California & $7.25 \%$ \\
\hline Colorado & $2.90 \%$ \\
\hline Connecticut & $6.35 \%$ \\
\hline Illinois & $6.25 \%$ \\
\hline New York & $4 \%$ \\
\hline North Carolina & $4.75 \%$ \\
\hline Rhode Island & $7 \%$ \\
\hline Texas & $6.25 \%$ \\
\hline Vermont & $6 \%$ \\
\hline
\end{tabular}

Figure 5: Ten States That Impose Sales Tax on EC Retailers - 2011 ${ }^{41}$

Note: Additional local sales taxes imposed by cities and counties are not included.

\section{CONCLUSION \& FUTURE IMPLICATIONS}

Overall, the benefits of taxing EC sales appear to outweigh the costs. However, there is no clear evidence of how EC positively or negatively affects traditional commerce on the state's economies or sales tax revenues as past studies provide inconsistent results. Therefore, it is also difficult to justify any tax policy change. It is especially important to consider taxation and its significant socio-economic consequences. It is essential that the system should be designed to achieve the appropriate trade-offs among revenue generation, allocation efficiency, equity, and administration and compliance costs. Lawmaking is usually slow and tedious; however, technology usually proceeds at unparalleled speeds. Taxation is a not a technological issue, but rather a legal issue. Therefore, for any future solution of this issue to be provided, governments and tax professionals should pay serious attention to and give consideration to the issue in order to avoid as much negative impact on the overall national economy as possible. Also, there is a significant need for further study, research, and analysis of the national economic effects of imposing new taxes on e-commerce in order to support law-makers in arriving at the most effective resolution.

\section{AUTHOR INFORMATION}

Hang Nguyen is an international student from Vietnam. She earned a BBA in International Business (with a concentration in Finance and Banking) and a BA in Spanish from Mississippi State University in December 2008. She recently graduated from Coastal Carolina University with a MBA in Accounting in December 2011 and has prepared to sit for the 2012 CPA. She can be reached at htnguyen@ coastal.edu

Meredith DeCenzo is currently a graduate student in the Masters of Accountancy program at Coastal Carolina University and will graduate in May 2012. Meredith graduated with honors from the University of North Carolina at Wilmington in May 2008 with a BA in Media Studies and Communication. She plans on taking the CPA examination beginning in the summer of 2012 and hopes to pursue a career in public accounting with a concentration in Auditing or Tax. She can be reached at mndecenz@coastal.edu

Dr. Meyer Drucker is a Distinguished Professor Emeritus of the University of South Carolina at Spartanburg. He is a CPA and has an LLM in Taxation from Emory University, along with a JD from University of South Carolina. He recently retired from Coastal Carolina University after over 45 years of college teaching, where he taught taxation in both the undergraduate and graduate programs for the past 5 years. He can be reached at meydrucker@aol.com (Corresponding author)

\footnotetext{
${ }^{41}$ United States Sales Tax Site: Table of Sales Tax Rates. Retrieved December 31, 2011 from United States Sales Tax Site: http://www.usa-sales-use-tax-e-commerce.com/table_sales_rates.asp 